\title{
Winter conditions in six European shallow lakes: a comparative synopsis
}

\author{
Martin T. Dokuli1 ${ }^{\mathrm{a} \bowtie}$, Alois Herzig ${ }^{\mathrm{a}}$, Boglárka Somogyi ${ }^{\mathrm{b}}$, Lajos Vörös ${ }^{\mathrm{b}}$, , \\ Karl Donabaum ${ }^{\mathrm{c}}$, Linda May ${ }^{\mathrm{d}}$, and Tiina Nõges ${ }^{\mathrm{e}}$ \\ ${ }^{a}$ Nationalpark Neusiedlersee-Seewinkel, 7142 Illmitz, Austria \\ ${ }^{\mathrm{b}}$ MTA Centre for Ecological Research, Balaton Limnological Institute, Klebelsberg K. 3, 8237 \\ Tihany, Hungary \\ ${ }^{\text {c }}{ }^{4}$ DWS Hydro-Ökologie GmbH, Zentagasse 47/5, 1050 Wien, Austria \\ ${ }^{\mathrm{d}}$ Centre for Ecology and Hydrology, Bush Estate, Penicuik, Midlothian EH26 OQB, Scotland, UK \\ ${ }^{\mathrm{e}}$ Centre for Limnology, Institute of Agricultural and Environmental Sciences, Estonian University \\ of Life Sciences, 61117 Rannu, Tartumaa, Estonia \\ ${ }^{凶}$ Corresponding author, martin.dokulil@univie.ac.at
}

Received 7 May 2014, revised 26 June 2014, accepted 1 July 2014

\begin{abstract}
This review summarizes winter conditions from six polymictic European shallow lakes. The lakes range from oligotrophic to hyper-eutrophic. Four of the lakes freeze regularly while ice cover is absent or rare in the two others. Ice duration and timing of ice-out are significantly influenced by climate signals in three of the lakes. Winter water temperature remains higher in nonice-covered lakes. No long-term trend in temperature is detectable except for one lake where winter water temperature began to increase in 1986. Secchi depth in winter is equal or greater than summer values in all six lakes indicating relatively better light conditions in winter. Total phosphorus concentration in winter ranges from 10 to $130 \mu \mathrm{g} \mathrm{L}{ }^{-1}$, which is equal or lower than summer values and is unrelated to chlorophyll $a$ in five of the sites. Phytoplankton species composition during winter differs largely at the six sites. The winter assemblages largely depend on the trophic level and the conditions during the previous season. Winter chlorophyll $a$ and phytoplankton biomass are usually lower than summer values because of reduced photosynthetic rates. Bacterial production often exceeds primary production. Epipelic algal assemblages tend to proliferate during winter in both ice-covered and non-ice-covered lakes. Primary production is low during winter because of insufficient light. Zooplankton abundances and biomass critically depend on conditions during the previous season and the winter situation and are quite variable from year to year, but their values correlate with the trophic status of the lakes. As a result, winter conditions are important to understand seasonal and annual changes in shallow lakes.
\end{abstract}

Key words: environment, temperature, phytoplankton, zooplankton, bacteria, primary production.

\section{INTRODUCTION}

Shallow lakes are very diverse ecological systems, which vary greatly in size and depth. Typically these lakes do not stratify for prolonged periods. The water column is frequently mixed and the lakes are therefore referred to as polymictic. Some shallow lakes appear turbid due to inorganic matter stirred up from the 
sediment. Others have clear water with a euphotic zone that extends to the bottom. Such lakes can be largely colonized by macrophytes. Shallow lakes can differ widely in water chemistry, ranging from humic to salty. In several regions of the world shallow lakes are more abundant and sometimes more important than deep lakes (Wetzel, 1990). In addition, they often have been created by human activity and may even have been constructed intentionally (e.g. Melbourne Water, 2005). The majority of these waters are non-linear ecosystems that can display discontinuities and hysteresis in their behaviour.

The winter situation differs considerably between deep and shallow lakes. Because of the smaller amount of latent heat stored in shallow waters, these freeze quickly and more regularly than deep lakes, which in many cases do not freeze at all. Turbid lakes often have a relatively better light climate under ice cover than at other times of the year due to the settling out of the particles under strongly reduced turbulence. Sediment dynamics play a much larger role in shallow systems than in deep ones because of intimate contact between the water and the sediments. In fact, it has been suggested that the sediment in shallow lakes is equivalent to the metalimnion in deep lakes (Olah, 1975).

The aim of this review is to summarize, analyse, and compare the winter aspects of six shallow lakes from across Europe varying in the duration of their ice cover. Winter conditions are contrasted with the summer situation.

\section{THE SITES}

Six shallow lakes were selected for this review mainly on the basis of the existence of long-term data. Geographically, the sites cover a large part of Europe. They differ in lake and catchment size, chemistry, and retention time but all are shallow and polymictic with only occasional thermal stratification (Table 1). The lakes differ greatly in their flushing rate and also include one seepage lake. Water transparency varies from clear to very turbid and the level of anthropogenic impacts differs considerably among sites resulting in trophic levels ranging from oligotrophic to hypertrophic. Winter conditions span from rare or only partly ice cover to regular ice covered.

\section{ORIGIN AND TREATMENT OF DATA}

All data analysed were supplied by the authors. Historical records from Lough Neagh were extracted and digitized from Wood and Smith (1993) using Grapher 9 software $\left(\right.$ RockWare $\left.^{\circledR}\right)$. Total phytoplankton biomass from Loch Leven was digitized for 1968-1976 from Bailey-Watts (1978) and for 2002-2007 from the reports available at http://nora.nerc.ac.uk/ .

The observation periods differ among lakes and are summarized in Table 1. Further information on each site may be found as follows: for Lough Neagh - Wood and Smith (1993), Loch Leven - Carvalho et al. (2007) and earlier reports, Lake 


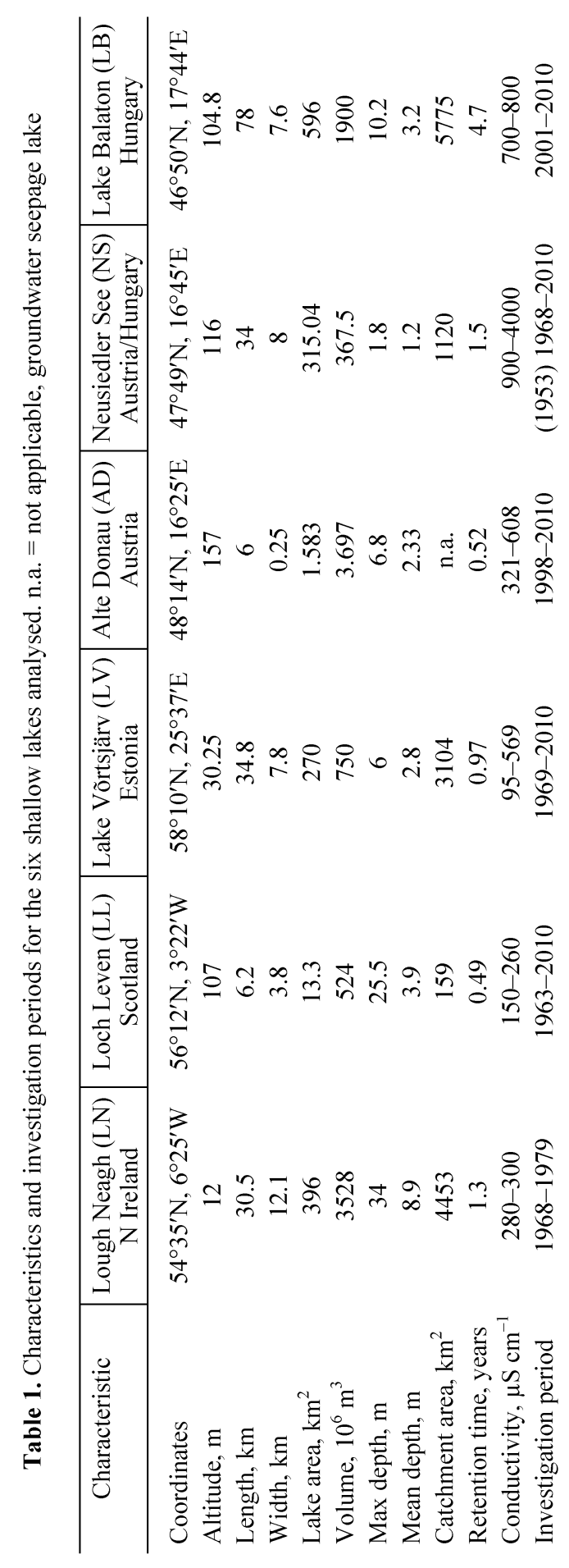


M. T. Dokulil et al.

Võrtsjärv - Haberman et al. (2004), Alte Donau - Dokulil et al. (2006, 2007), Neusiedler See - Löffler (1979) and Dokulil and Herzig (2009), and Lake Balaton - Tátrai et al. (2008).

Winter data were extracted from the data banks corresponding to measurements during the months of December, January, and February (DJF). These results were contrasted with summer observations representative of June, July, and August (JJA) for each site. All data were checked for consistency and tested for normality (Kolmogorov-Smirnov). Statistical analysis was performed using SigmaStat ${ }^{\circledR}$ 3.5. Statistical differences between variables were tested using either $F$-test plus $t$-test or Kruskal-Wallis. Graphs were made with SigmaPlot ${ }^{\circledR} 10$ while Minitab $^{\circledR} 15$ was used for box-whisker plots. Surfer 8 software (RockWare ${ }^{\circledR}$ ) was utilized for the contour plot. To visualize break points, rescaled adjusted partial sums (RAPS) were calculated according to Garbrecht and Fernandez (1994).

\section{WINTER CONDITIONS}

In the temperate zone, climatic conditions in winter differ fundamentally from those in summer. Air temperature is a lot lower, often below freezing, resulting in ice coverage of lakes in many regions. Day length is shorter and both solar radiation and photosynthetic available radiation (PAR) are about five to six times lower.

Important alterations are caused by the ice cover sealing the water column for prolonged times. Ice cover is rare or only intermittent in Lough Neagh and Loch Leven (Lyle, 1981). The duration of ice cover is on average 50 days (0-96) in Lake Balaton, 56 days (0-116) in Neusiedler See, and 131 days (55-170) in Lake Võrtsjärv. In spite of the significant increase of winter air temperature in Estonia (by $0.59 \pm 0.28^{\circ} \mathrm{C}$ per decade in $1961-2011, P<0.05$ ), the ice cover duration in Lake Vorrtsjärv has not changed (Nõges and Nõges, 2014). This demonstrates the nonlinearity of the relationship between air temperature (AT) and the freeze-up and breakup dates (Järvet, 2004).

Ice duration and timing of ice-out are influenced by long-distance climate signals in Neusiedler See, Balaton, and in several Polish shallow lakes (Skowron, 2008; Dokulil and Herzig, 2009; Vörös et al., 2009). From these observations, a decline in ice duration at a rate of about 0.5 days per year can be deduced for these lakes.

The ice cover also protects the water column from wind-induced mixing, causing an inverse vertical temperature gradient. Water temperature gradually increases from $0^{\circ} \mathrm{C}$ at the ice-water interface up to $4{ }^{\circ} \mathrm{C}$ or higher in the bottom layers. Differences in winter water temperature between lakes mainly result from differences in ice cover. Shallow lakes that have no, irregular, or partial ice cover, such as Lough Neagh and Loch Leven, have on average higher water temperatures than those that are regularly covered by ice in winter (Fig. 1). The greatest variability in winter temperature, which also differs significantly in Lough Neagh, has been observed in Loch Leven. Conditions in all the four other lakes 


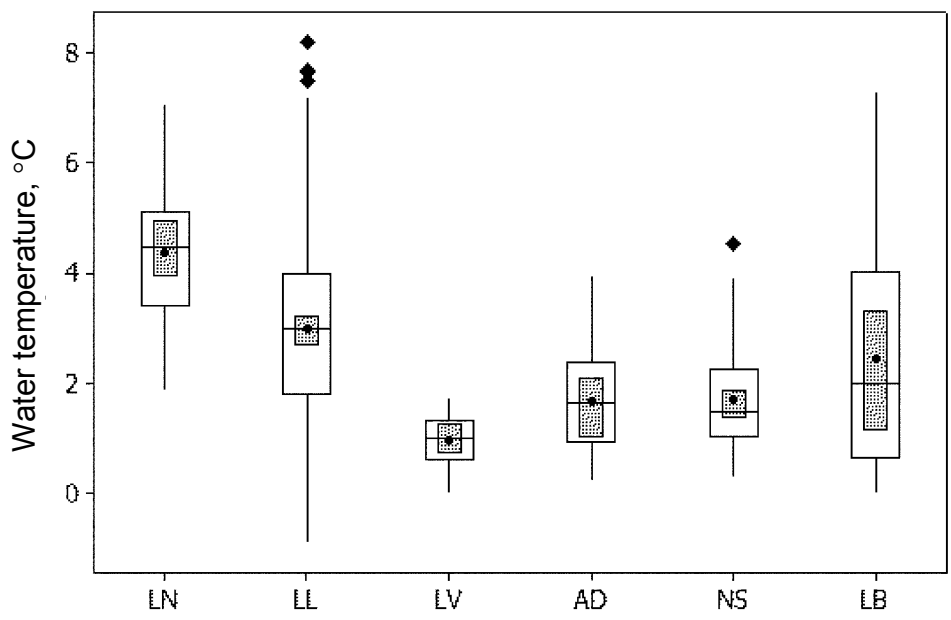

Fig. 1. Box-whisker plot of winter water temperature in six European shallow lakes. The horizontal line is the median, the shaded box is the $95 \%$ confidence limits of the median, box limits are quartiles, and the black dot is the mean. Black diamonds indicate outliers. Abbreviations as in Table 1.

are similar. No significant trends in the time series are discernible except in Neusiedler See where temperatures increased at a rate of about $0.07^{\circ} \mathrm{C}$ per year from 1986 onwards as indicated by the partial sums (Fig. 2).

Vertical attenuation coefficients under the ice $\left(0.4-1.3 \mathrm{~m}^{-1}\right)$ indicate relatively better light conditions compared to the summer situation both in Lake Balaton and Neusiedler See (Dokulil, 1979; Vörös et al., 2009). In both cases, improvement is due to the sedimentation of inorganic particles under the ice cover. In the groundwater seepage lake Alte Donau the under-water light conditions were less variable $\left(0.79 \pm 0.26\right.$ and $0.93 \pm 0.25 \mathrm{~m}^{-1}$ for winter and summer, respectively) but were significantly better under ice.

Lake Võrtsjärv is rather turbid in summer with Secchi depth less than $1 \mathrm{~m}$ while in winter Secchi may reach up to 2.5-3.2 m (Reinart and Nõges, 2004). Under-ice light conditions in Võrtsjärv depend on the thickness of the ice and snow cover on it, which varies greatly during winter and in different parts of the lake. The attenuation of light in the ice under average ice conditions ranges from $4 \%$ in December to about $26 \%$ in March. In warm winters about $10 \%$ of incident PAR is transmitted through the ice and snow cover while in cold winters it is less than $0.1 \%$. Incident PAR increases from December to April; however, because of the properties of the ice cover, minimum values of under-ice PAR occur in February and March. According to investigations by Leppäranta et al. (2003) that include Lake Võrtsjärv, the light field under snow and ice cover is more diffuse than the open water situation. Scalar irradiance is therefore higher than PAR measured conventionally by planar sensors. Moreover, the spectral distribution is also different (Dokulil, 1979; Lei et al., 2011). The concentrations of suspended matter and chlorophyll $a$ as well as the beam attenuation coefficient under the ice are markedly lower than the maxima during the ice-free period. 


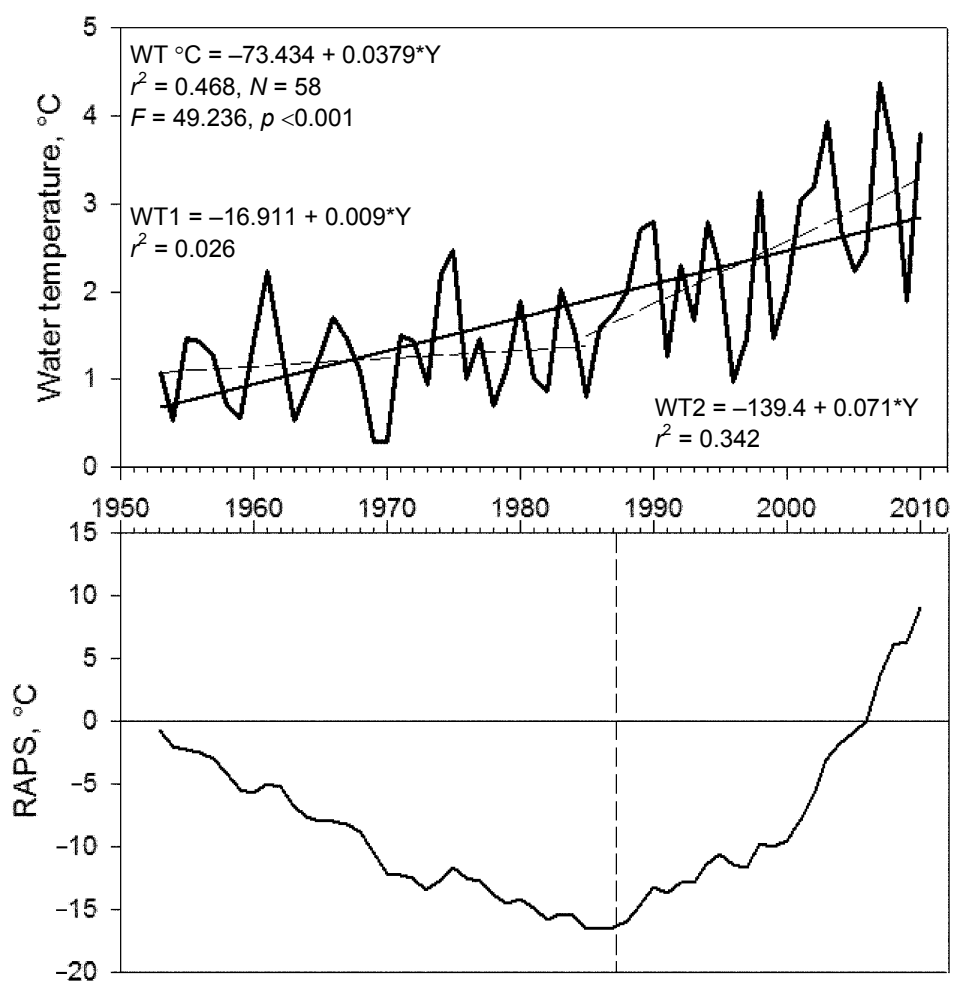

Fig. 2. Upper panel: winter water temperatures (WT) in Neusiedler See 1953-2010. Regression and correlation details are inserted. WT1 = WT for the period 1953-1985, WT2 = same for 1986-2010. Lower panel: re-adjusted partial sums (RAPS) of WT.

Optical properties for Lough Neagh are described by Jewson (1993a, 1993b). These indicate that in this lake vertical attenuation coefficients during winter are not significantly different from the summer season.

Secchi disk readings were used to compare the under-water light situation in the six lakes analysed here (Fig. 3). In all but one lake, Secchi depth was significantly greater in winter than in summer, indicating relatively better light conditions although snow and ice can absorb up to $80 \%$ of the incident radiation (Petrov et al., 2005). No differences between winter and summer under-water light conditions were observed in Loch Leven, a lake which is mostly ice free during winter.

Mean total phosphorus (TP) concentrations were rather different among the six lakes, ranging from less than $10 \mu \mathrm{g} \mathrm{L}^{-1}$ (oligotrophic) to $130 \mu \mathrm{g} \mathrm{L}^{-1}$ (hypertrophic). Winter TP concentrations were highest and significantly different from all other sites in Lough Neagh (Fig. 4). The present winter situation cannot be deduced from these historical data but should be judged from the information available: TP concentrations appear to have increased further up to an annual 


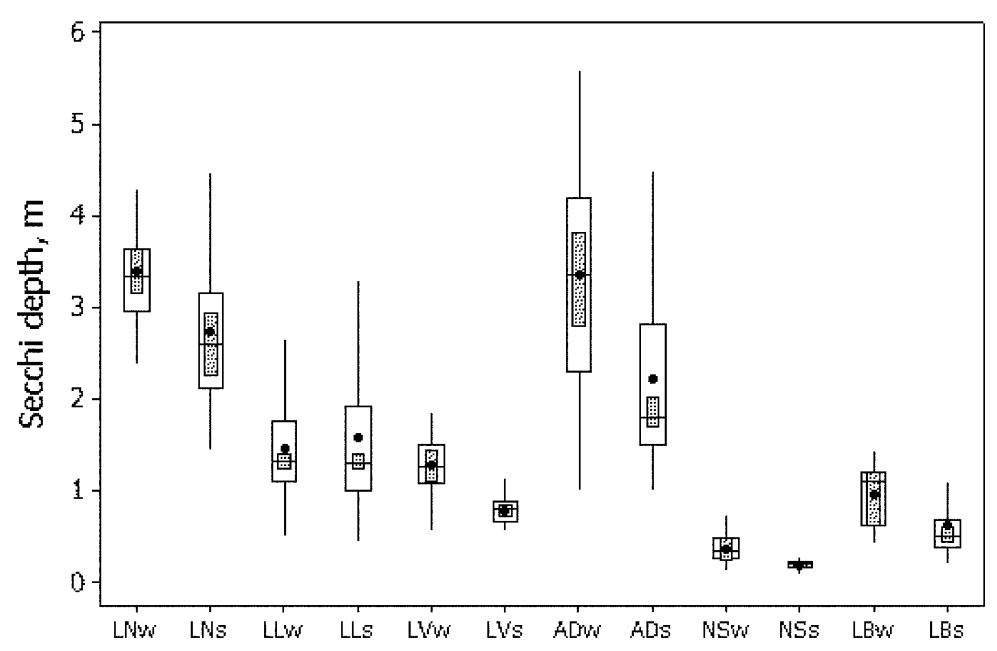

Fig. 3. Box-whisker plot of winter and summer Secchi depth in six European shallow lakes. Explanation and abbreviations as in Fig. 1 and Table 1.

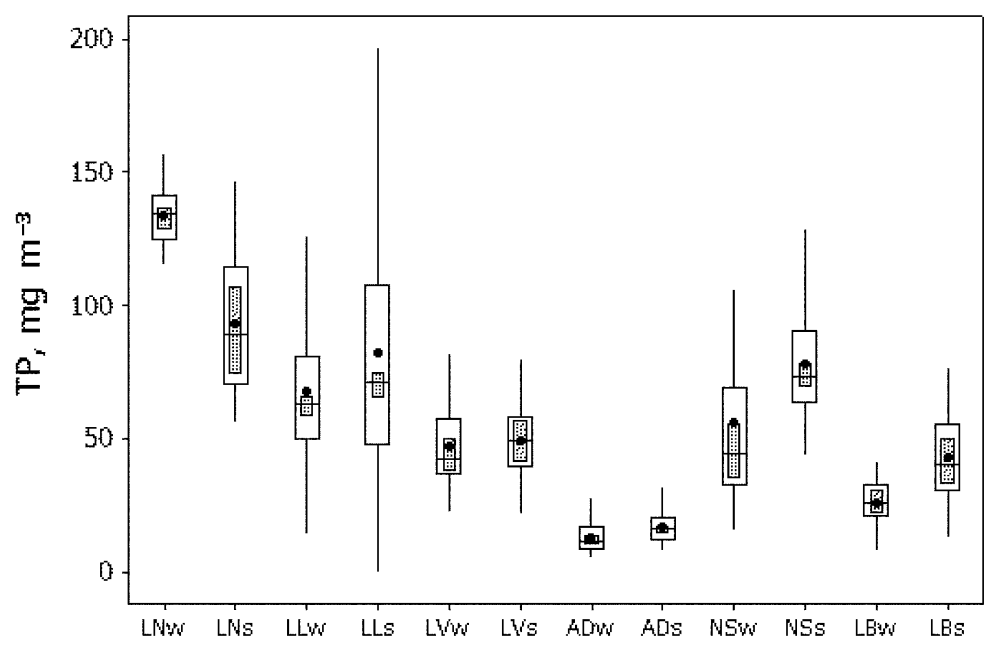

Fig. 4. Box-whisker plot of winter and summer total phosphorus (TP) concentrations in six European shallow lakes. Explanation and abbreviations as in Fig. 1 and Table 1.

average of $146 \mu \mathrm{g} \mathrm{L}^{-1}$ despite efforts to reduce external loading (Foy et al., 2003; Foy and Lennox, 2006). So winter conditions should have remained the same or even worsened.

In Loch Leven TP was highly variable and significantly different between winter and summer. This is similar to the conditions in Lake Võrtsjärv. The lowest TP concentrations were observed in Alte Donau in both winter and summer, which is a reflection of the small variation in the supply from the groundwater. In 
Neusiedler See and Lake Balaton TP concentrations were significantly higher in summer than in winter (Fig. 4), indicating either a much larger external nutrient load during summer or phosphorus adsorbed to suspended solids, which is biologically unavailable (Gunatilaka, 1982, 1988).

\section{PHYTOPLANKTON}

Chlorophyll $a$ as a measure of phytoplankton biomass was always significantly lower in winter than in summer except in Neusiedler See where values were not significantly different (Fig. 5). The range of chlorophyll $a$ values is usually much larger in summer but in Neusiedler See both seasons have almost identical ranges. Seasonal chlorophyll $a$ concentrations were uncorrelated to seasonal TP values in five of the six sites. The reason for this discrepancy is the greater loading of TP from the catchment in winter, which can not be utilized by phytoplankton due to low light and hence low photosynthetic rates. In addition, a large fraction of TP can be adsorbed to suspended solids and is therefore biologically not available. A correlation between chlorophyll $a$ and TP was only observed in Alte Donau $(r=0.58, n=70, p<0.0001$ for winter and $r=0.67, n=91, p<0.0001$ for summer), perhaps as a result of the seepage supply of phosphorus.

The chlorophyll $a$ content of the phytoplankton biomass in Lake Balaton varies between $0.3 \%$ and $0.5 \%$ in the productive period of the year (Vörös and Padisák, 1991) but increases to $1.5-2.0 \%$ in winter. This increase in the cellular content of chlorophyll $a$ is a result of shade acclimation of the winter assemblage. As a consequence, winter phytoplankton biomass is overestimated when converted from chlorophyll $a$ measurements.

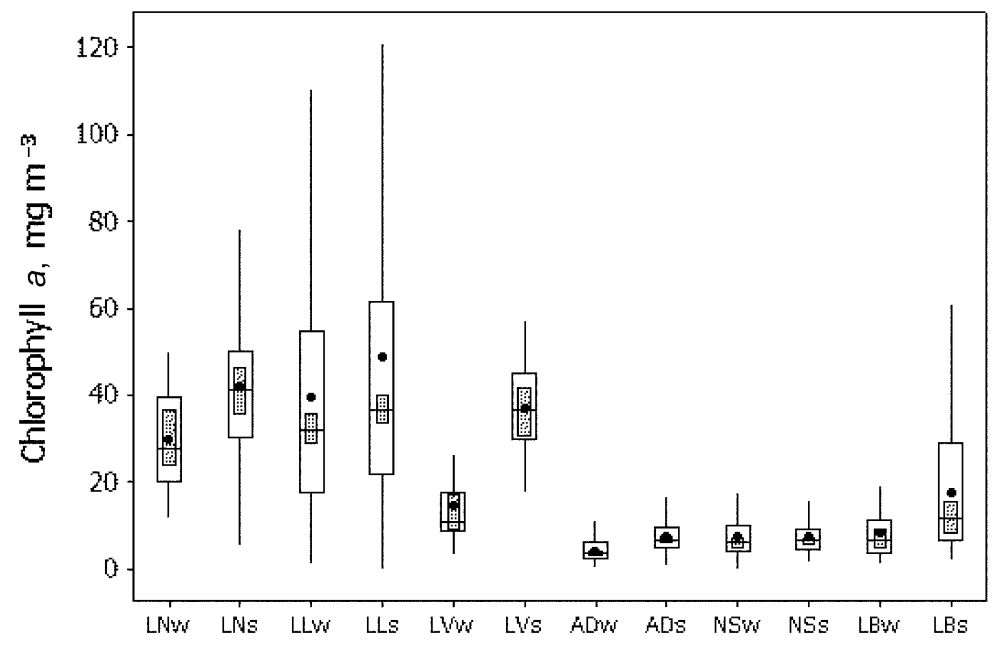

Fig. 5. Box-whisker plot of winter and summer chlorophyll $a$ concentrations in six European shallow lakes. Explanation and abbreviations as in Fig. 1 and Table 1. 
Results for phytoplankton total biomass (PTB) indicated that winter data were significantly different from summer crops except in Lough Neagh and Loch Leven (Fig. 6). Average and median values are usually lower during winter and concentrations less variable. In Loch Leven, however, winter biomass is even higher than summer biomass as a consequence of spring peaks that occurred as early as February in several years (see Bailey-Watts, 1978, figs 6 and 8, and reports at http://nora.nerc.ac.uk). The lowest average winter biomass $\left(0.9 \mathrm{~g} \mathrm{~m}^{-3}\right.$ fresh weight (fw)) occurred in Alte Donau.

Phytoplankton species composition during winter can be dissimilar among shallow lakes. Small-sized algae $\left(<100 \mu \mathrm{m}^{3}\right)$ repeatedly dominate. Algae with high surface to volume ratio (e.g. Monoraphidium sp.) or small to medium-sized spherical actively moving flagellates (Cryptomonas sp., Rhodomonas minuta) compensate the increased sinking in winter due to the reduced vertical mixing of the water column (Teubner and Dokulil, 2000; Phillips and Fawley, 2002).

The historical data from Lough Neagh indicated a considerable contribution of cyanobacteria to the total winter biomass particularly from Limnothrix redekei and Planktothrix agardhii. In some years even the nitrogen fixing species Aphanizomenon flos-aquae and Anabaena flos-aquae appeared in small quantities. The diatoms Aulacoseira italica subarctica, A. italica, and A. subarctica and Stephanodiscus contributed to winter biomass. More 'typical' winter species such as Rhodomonas only produced a small biomass and did not peak before April or May. We could not find a more recent description of the species assemblage in Lough Neagh, but all evidence suggests that nutrients have further increased and hypertrophic conditions prevail (McMurray et al., 2002).

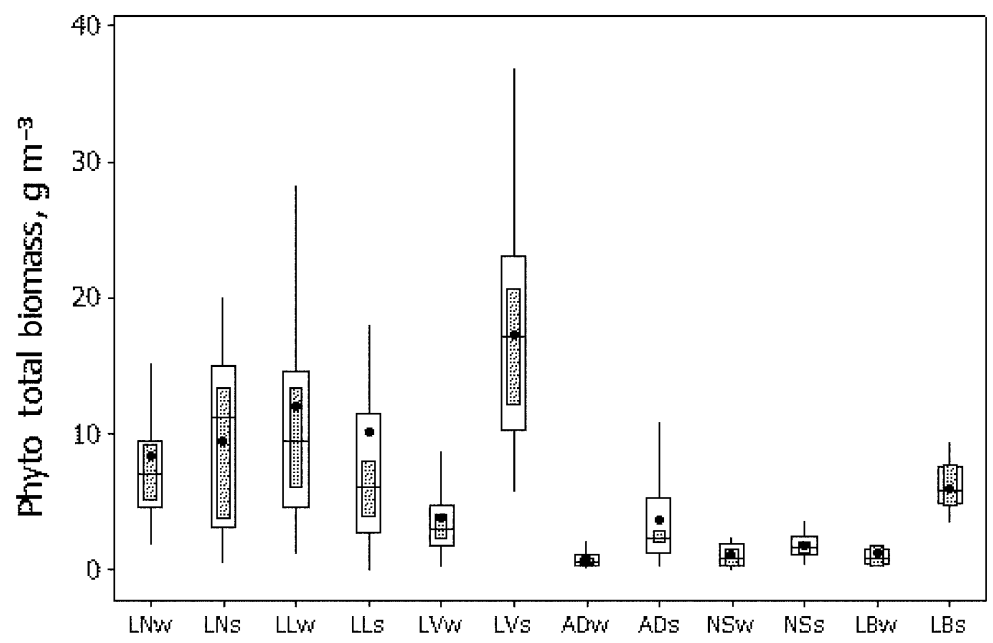

Fig. 6. Box-whisker plot of winter and summer phytoplankton total biomass in six European shallow lakes. Explanation and abbreviations as in Fig. 1 and Table 1. 
M. T. Dokulil et al.

Loch Leven winter phytoplankton has been very variable over the years. In the early years (1968-1970) L. redekei was associated with small unicellular centric diatoms, Diatoma elongatum and Asterionella formosa, and a species of Synechococcus (Bailey-Watts, 1978). In the winter periods of 1971 to 1976 centric diatom species and A. formosa were accompanied by $A$. flos-aquae. These were supplemented by Aulacoseira ambigua from the winter of 1974/75 onwards. More recent information, i.e. for the years 1999-2007, indicates high variability among years in terms of both quality and quantity. In some of the years biomass was highest during winter (e.g. 1999 and 2002). This was associated with domination by A. italica, which tended to take over completely from 2004 onwards although winter biomass remained variable. Other years, such as 2001 and 2003, were characterized by a mixture of small centric diatoms, A. italica and cryptophytes. Within these nine years, the winter of 1999/2000 was exceptional because $P$. agardhii dominated the phytoplankton community. This species had already appeared sporadically between 1974 and 1979. Changes in the phytoplankton species composition and the strong year-to-year variability in Loch Leven have been ascribed to the highly inconsistent flushing rate (Bailey-Watts et al., 1990).

Winter phytoplankton in Lake Võrtsjärv is usually light-limited. Laugaste (1978) carried out a special investigation of winter phytoplankton in 1971-1975. The long-term average of winter biomass in Võrtsjärv was $8 \mathrm{~g} \mathrm{~m}^{-3}$ (median 3.1). The species composition during winter did not differ much from the preceding season, consisting of diatom and cyanobacteria species that have not yet settled or are occasionally re-suspended from the bottom. Under-ice development of the phytoplankton in March-April is initiated by sunlight penetrating through the ice. Fast-growing small flagellates are the first to respond to the improvement of light conditions. In some years, under-ice blooms of Aulacoseira islandica were observed with biomass reaching up to $10 \mathrm{~g} \mathrm{~m}^{-3} \mathrm{fw}$ (Nõges et al., 2004).

The phytoplankton assemblage in Alte Donau was dominated by Cylindrospermopsis raciborskii in the winters of 1993 and 1994. After remediation in 1995 the water quality improved considerably and winter crops were initially dominated by diatoms, later gradually shifting to dominance by Cryptophyta (Rhodomonas minuta, $R$. sp., Cryptomonas erosa, and C. marssonii) and small flagellates from the Chrysophyta group.

The species composition in Neusiedler See has dramatically changed in recent decades from mainly diatoms to dominance by cyanobacteria (Fig. 7; Dokulil and Herzig, 2009, fig. 2a). In addition, Cryptophyta contributed significantly to winter biomass in the 1990s. Green algae slightly increased in the early 1990s but never gained high importance.

In Lake Balaton picoeukaryotes dominated the winter picoplankton, often constituting half of the total phytoplankton biomass (Vörös et al., 2009). Winter assemblages were characterized by small flagellates from the genera such as Cryptomonas, Rhodomonas, Chrysochromulina, other small flagellates, and some coccal green algae. Winter blooms of dinoflagellates or chrysophytes occurred but their presence was unpredictable (ECOSURV, 2005). 


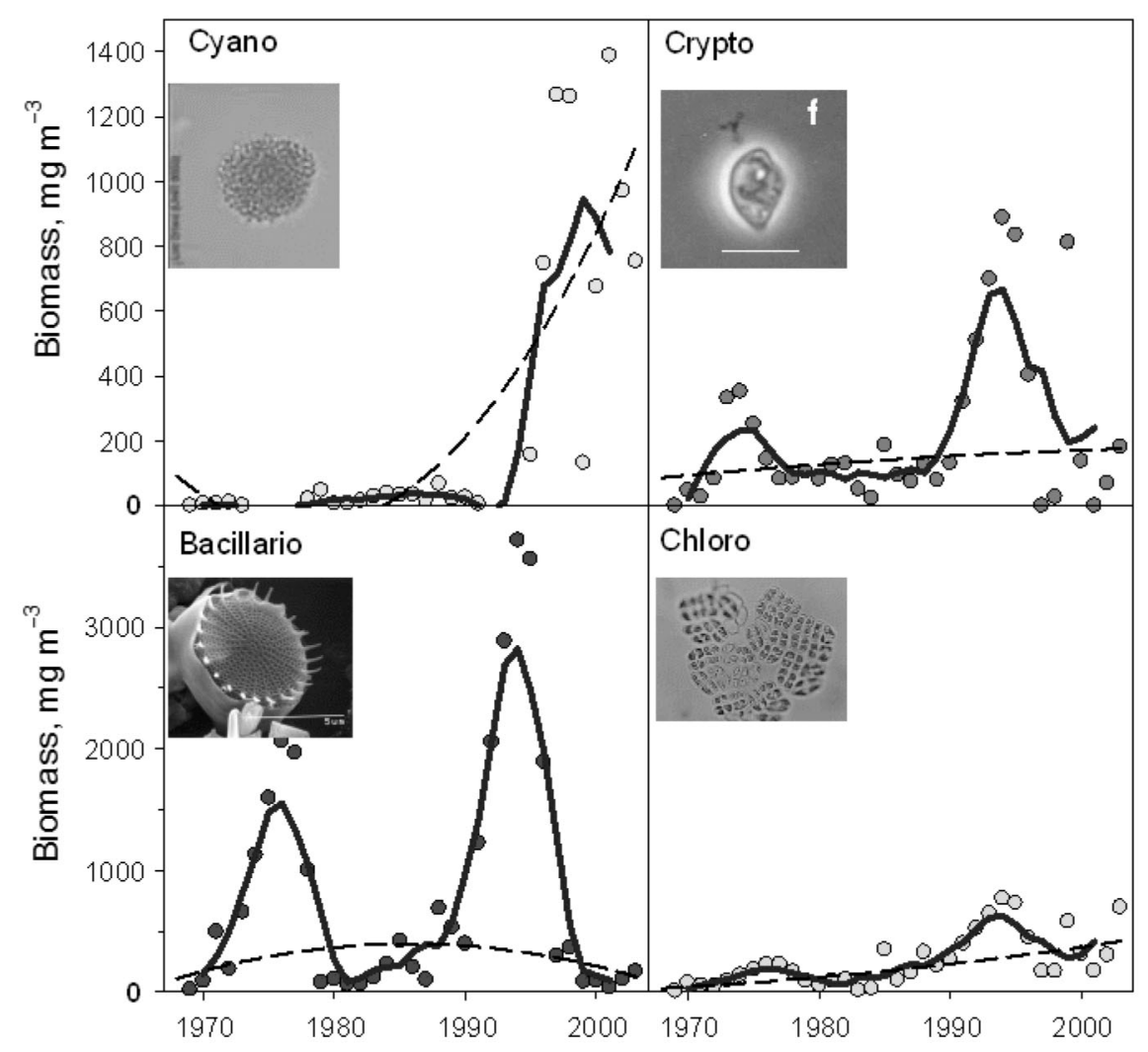

Fig. 7. Long-term development of group-specific biomass in the winters of 1969-2006 in Neusiedler See. Cyano = Cyanobacateria; Crypto $=$ Cryptophyta; Bacillario = Bacillariophyta (diatoms); Chloro $=$ Chlorophyta.

\section{EPIPELIC ALGAE}

The development of epipelic algal communities in winter was favoured by the relatively better light conditions of lakes that are highly turbid for most of the year. In Neusiedler See for instance a strong inshore-offshore distribution pattern was observed (Fig. 8). The total biovolume of the epipelic algae, mainly composed of diatoms, was the highest near the reed fringe, it decreased with distance from the reeds and reached the greatest spatial expansion during winter ice cover. The potential production of epipelic algae was also the highest during winter (Khondker and Dokulil, 1986, 1987).

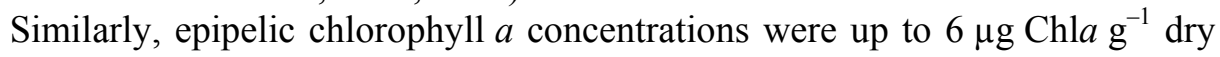
weight (dw) in winter in Loch Leven when water clarity was highest (Spears et al., 2010). The structure of the epipelon community varied strongly with depth. The sediment surface was dominated by diatoms in shallow water, cyanobacteria in deeper water, and sites of intermediate depth returned the highest estimated biovolume and the most diverse communities. 


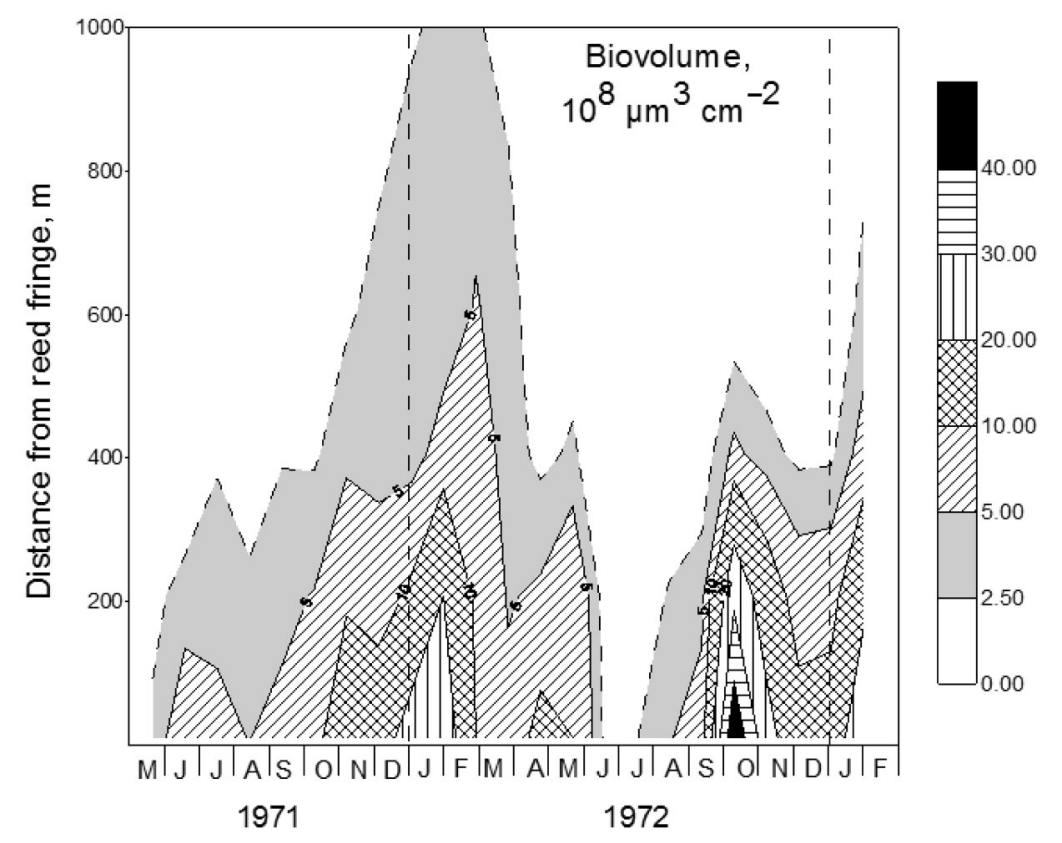

Fig. 8. Contour plot of fresh weight biovolume of epipelic algae in front of the reed belt in Neusiedler See. After Prosser in Schiemer, 1979.

The diatom spectrum on the surface sediment of Lough Neagh was mainly composed of planktonic forms and small epipelic and epipsammic forms such as Fragilaria construens, Amphora ovalis, and others (Batterbee and Carter, 1993).

\section{AUTOTROPHIC PRIMARY AND BACTERIAL PRODUCTION}

Measurements of photosynthetic rates are mainly confined to the productive periods of the year. In winter low temperature together with low incoming solar radiation and attenuation through ice and snow or by inorganic turbidity in non-ice covered lakes restrict photosynthesis and hence algal growth.

Comparative estimation of photosynthesis-irradiance $(P-I)$ curves of the phytoplankton in Lake Balaton and Neusiedler See revealed seasonal differences. Light inhibition was observed in winter, indicating acclimation to low light intensity, while light-saturated $P-I$ curves were obtained in summer (Fig. 9). In both lakes the chlorophyll-specific maximum photosynthetic rate $\left(P_{\max }\right)$ was approximately 6-fold lower in winter (Lake Balaton: $0.78 \pm 0.16 \mu \mathrm{g} \mathrm{C} \mu \mathrm{g} \mathrm{Chl} a^{-1} \mathrm{~h}^{-1}$, Neusiedler See: $0.59 \pm 0.03 \mu \mathrm{g} \mathrm{C} \mu \mathrm{g} \mathrm{Chl} a^{-1} \mathrm{~h}^{-1}$ ) than in summer (Lake Balaton: $4.84 \pm 0.8 \mu \mathrm{g} \mathrm{C} \mu \mathrm{g} \mathrm{Chl} a^{-1} \mathrm{~h}^{-1}$, Neusiedler See: $\left.3.55 \pm 0.43 \mu \mathrm{g} \mathrm{C} \mu \mathrm{g} \mathrm{Chl} a^{-1} \mathrm{~h}^{-1}\right)$. The light saturation parameter $\left(I_{\mathrm{k}}\right)$ and the optimal light intensity $\left(I_{\mathrm{opt}}\right)$ were also much lower in winter (Lake Balaton: $I_{\mathrm{k}}: 55.9 \mu \mathrm{mol} \mathrm{m} \mathrm{s}^{-2}, I_{\mathrm{opt}}: 169 \mu \mathrm{mol} \mathrm{m}^{-2} \mathrm{~s}^{-1}$; Neusiedler See: $I_{\mathrm{k}}: 30 \mu \mathrm{mol} \mathrm{m} \mathrm{m}^{-2}, I_{\mathrm{opt}}: 125 \mu \mathrm{mol} \mathrm{m}^{-2} \mathrm{~s}^{-1}$ ) than in summer 

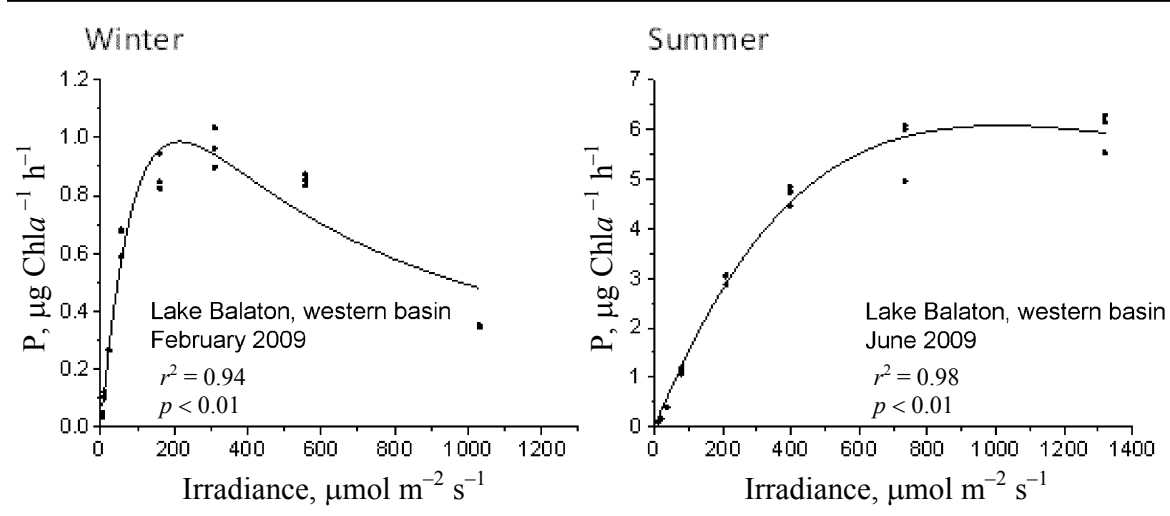

Fig. 9. Photosynthesis-irradiance relationship of the total phytoplankton in the western basin of Lake Balaton in winter and summer 2009.

(Lake Balaton: $I_{\mathrm{k}}: 303 \mu \mathrm{mol} \mathrm{m}{ }^{-2} \mathrm{~s}^{-1}, I_{\mathrm{opt}}: 704 \mu \mathrm{mol} \mathrm{m}{ }^{-2} \mathrm{~s}^{-1}$; Neusiedler See:

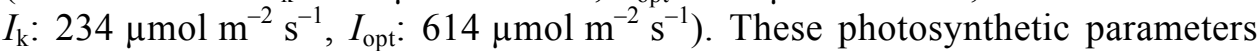
indicate a pronounced shade adaptation of the phytoplankton in winter and are in agreement with the higher chlorophyll $a$ content of the phytoplankton biomass (Ágyi et al., 2009).

Phytoplankton and bacterial production under ice cover was estimated in Neusiedler See during the winter of $1995 / 96$ by Reitner et al. $(1997,1999)$. At a

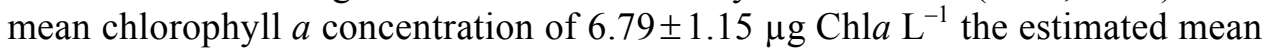
water column production of phytoplankton was $2.46 \pm 1.06 \mathrm{mg} \mathrm{C} \mathrm{m}^{-2} \mathrm{~d}^{-1}$ while the mean bacterial production amounted to $15.3 \pm 12.8 \mathrm{mg} \mathrm{C} \mathrm{m}^{-2} \mathrm{~d}^{-1}$. Since phytoplankton production was only $16 \%$ of bacterial production it alone cannot support bacterial growth. Most likely bacterioplankton were using other carbon sources such as dissolved organic carbon remaining from the previous season or exported from the reed belt.

Photosynthetic carbon uptake during winter was $89.9 \pm 75.9 \mathrm{mg} \mathrm{C} \mathrm{m}^{-2} \mathrm{~d}^{-1}$ in Alte Donau for the period 1995-2001. Due to the high community respiration (57\%) the 24-hour carbon balance was negative most of the time. Chlorophyll-specific maximum photosynthetic rates $\left(P_{\max }\right)$ were low $\left(1.08 \pm 0.58 \mathrm{mg} \mathrm{C} \mathrm{mg} \mathrm{Chl} a^{-1} \mathrm{~h}^{-1}\right)$ and became light saturated $\left(E_{\mathrm{k}}\right)$ at $51 \pm 23 \mu \mathrm{mol}$ photons $\mathrm{m}^{-2} \mathrm{~s}^{-1}$. Correspondingly, the efficiency at low light intensity $(\alpha)$ was $0.022 \pm 0.012 \mathrm{mg} \mathrm{C} \mathrm{mg} \mathrm{Chla}{ }^{-1}$ $\left(\mu \mathrm{mol} \text { photons } \mathrm{m}^{-2} \mathrm{~s}^{-1}\right)^{-1}$.

In Lake Võrtsjärv the mean winter primary production was about $31 \mathrm{mg} \mathrm{C} \mathrm{m}^{-2} \mathrm{~d}^{-1}$ (Nõges and Nõges, 1998; Nõges et al., 2011) and bacterial production during winter was generally less than $150 \mathrm{mg} \mathrm{C} \mathrm{m}^{-2} \mathrm{~d}^{-1}$ (Kisand and Nõges, 2004). Both these values are about 10 times higher than those in Neusiedler See.

Much higher primary production rates in winter were reported for Lough Neagh and Loch Leven. Daily gross photosynthesis during January and February ranged from 80 to $200 \mathrm{mg} \mathrm{C} \mathrm{m}^{-2} \mathrm{~d}^{-1}$ in Lough Neagh (Jewson, 1993a, 1993b). Similar values were measured in the western basin of Lake Balaton, where 
M. T. Dokulil et al.

daily gross photosynthesis ranged between 100 and $200 \mathrm{mg} \mathrm{C} \mathrm{m}^{-2} \mathrm{~d}^{-1}$ in winter (Somogyi, 2010). Even higher winter production values of 300 to $1900 \mathrm{mg} \mathrm{C} \mathrm{m}^{-2} \mathrm{~d}^{-1}$ were reported from Loch Leven (Bindloss, 1974).

\section{ZOOPLANKTON}

Analysis of zooplankton communities of 16 European lakes from latitudes between $60^{\circ} \mathrm{N}$ and $44^{\circ} \mathrm{N}$ revealed the presence of $20-25$ species, with $2-5$ rotifers and 1-3 copepods being dominant; both cold-water species and perennial, eurythermal species contributed to the zooplankton community (Dokulil and Herzig, 2009). Identical results were obtained when analysing the data sets of the lakes discussed in this study. Specimens of the Synchaeta tremula-oblonga group, Notholca spp., and Keratella cochlearis prevailed in the rotifer plankton and Eudiaptomus gracilis and Cyclops spp. dominated the copepod community. In Lough Neagh and Loch Leven Daphnia spp. and in Alte Donau Bosmina sp. occurred in the winter plankton. As Neusiedler See has high alkalinity and high conductivity, its zooplankton species composition differs from that of the other European lakes. For example, although the same rotifer species prevailed in this lake as in other European lakes, the winter plankton has been dominated by the rotifer Rhinoglena fertöensis, a cold stenothermic specialist species inhabiting athalassic (i.e. non-marine), saline water bodies, in most years since the 1980s. The dominant calanoid copepod, Arctodiaptomus spinosus, is a typical crustacean of sodium lakes and a eurythermic species reproducing at a wide range of temperatures (Dokulil and Herzig, 2009).

The winter zooplankton abundance and biomass in Neusiedler See varied among years but correlated positively with chlorophyll $a$ concentrations. The degree of survival of autumn populations determined the zooplankton biomass in early winter. Zooplankton dynamics critically depend on the biomass in autumn and on conditions during the following winter, specifically ice conditions. Longterm data reveal that rotifer communities can vary annually (Dokulil and Herzig, 2009).

The winter abundance of zooplankton in Lough Neagh comprised on average 37 ind. $\mathrm{L}^{-1}$ rotifers and 17 ind. $\mathrm{L}^{-1}$ crustaceans (Fitzsimons and Andrew, 1993). In the eutrophic Lake Vortsjärv the corresponding numbers were 142 ind. $\mathrm{L}^{-1}$ rotifers and 64 ind. $\mathrm{L}^{-1}$ crustaceans. In this lake, zooplankton production during winter accounts for only $2.4 \%$ of the annual production (Haberman and Virro, 2004). In Loch Leven 93 ind. $\mathrm{L}^{-1}$ rotifers (1977-1978) and 33 ind. $\mathrm{L}^{-1}$ crustacea were recorded as mean numbers (Johnson and Walker, 1974), whereas in Lake Balaton, the mean numbers were 32 ind. $\mathrm{L}^{-1}$ rotifers and 100 ind. $\mathrm{L}^{-1}$ crustaceans (Zánkai and Ponyi, 1986; Zánkai, 1989).

The zooplankton abundance in Alte Donau was low, having mean densities of 22 rotifers $\mathrm{L}^{-1}$ and 34 crustaceans $\mathrm{L}^{-1}$. All values fall within the mean winter densities of Neusiedler See (1970-2004): 3-366 ind. $\mathrm{L}^{-1}$ rotifers and 26-118 ind. $\mathrm{L}^{-1}$ 
crustaceans (table 7 in Dokulil and Herzig, 2009). The same is true for the mean total winter biomass levels of zooplankton, which range from $32 \mu \mathrm{g} \mathrm{dw} \mathrm{L}^{-1}$ to $210 \mu \mathrm{g} \mathrm{dw} \mathrm{L}{ }^{-1}$ in Neusiedler See (table 8 in Dokulil and Herzig, 2009).

\section{SUMMARY AND CONCLUSIONS}

Ice conditions during winter affect many variables of lakes. Lakes with no or rare ice cover tend to have similar or higher values than those that are regularly covered by ice in winter. An example of how variables may be affected by ice or no ice is given in Fig. 10 for Neusiedler See. In a year with no ice zooplankton biomass was almost unaffected and chlorophyll $a$ concentrations were lower compared to a year with a long ice coverage. In contrast, total phosphorus, total phytoplankton biomass, and cyanobacterial biomass were higher when the lake was not covered with ice at all.

Phytoplankton structure, biomass, and dynamics during winter largely depend on the previous season, ice conditions, and climate change. Increased winter water temperature, among other factors, leads to changes in species composition. Depending on winter duration, the species assemblage can affect phytoplankton development in spring (Laugaste et al., 2010). Moreover, earlier ice break-up may affect phytoplankton development (Reinart and Pärn, 2006). In Lake Võrtsjärv warmer winters resulted in more thaw days during winter, earlier ice break-up in spring, and a higher lake water level for the whole year. Elevated temperature in winter stimulated the development of phytoplankton in spring. Diatoms reacted to

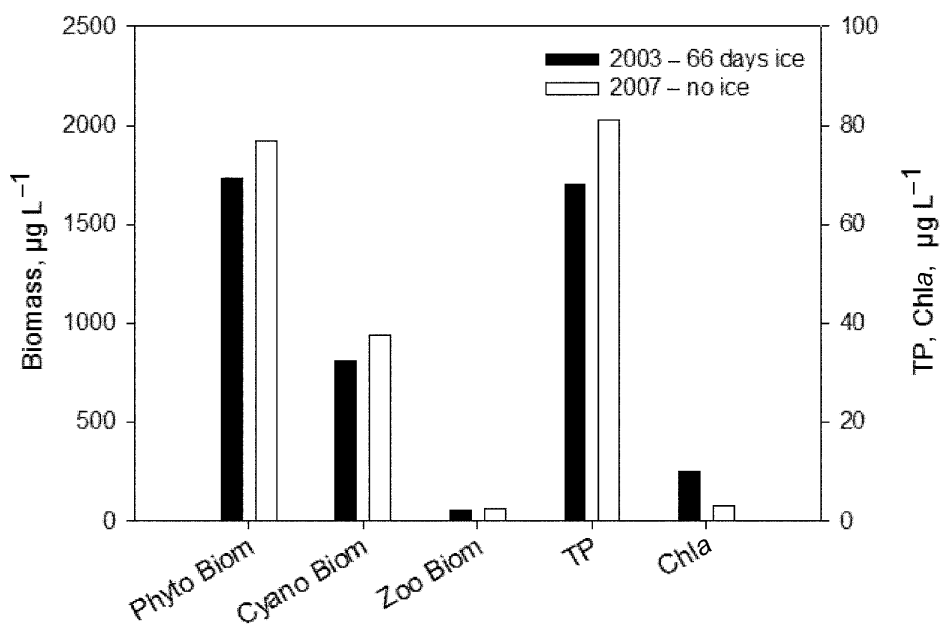

Fig. 10. Comparison of annual phytoplankton biomass (Phyto Biom), cyanobacterial biomass (Cyano Biom), zooplankton biomass (Zoo Biom), total phosphorus (TP), and chlorophyll $a$ (Chla) in Neusiedler See for the year 2003 with 66 days of ice cover and 2007, a year without ice. 
the improvement of under-ice light conditions in mild winters, and cyanobacteria to the earlier warming of water corresponding to earlier break-up of ice (Nõges, 2004; Nõges et al., 2010).

Epipelic algal assemblages tend to proliferate during winter in both ice covered and non-ice covered lakes. This is due to the relatively better under-water light conditions.

Primary production is usually low during winter because of insufficient incoming solar radiation. Photosynthetic rates, however, are a direct reflection of the trophic situation, being higher in more eutrophic conditions. Whether algal growth during winter can supply enough dissolved organic carbon to sustain bacterial growth and production is a point that needs further investigation.

Zooplankton abundances and biomass seem to critically depend on conditions during the previous season and the winter situation. The structure and quantity of the winter zooplankton can therefore vary strongly from one winter to the next. Although the abundance and biomass of zooplankton are quite variable from year to year, their values correlate with the trophic status of the lakes (Dokulil and Herzig, 2009).

From the observations reviewed above it can be concluded that winter conditions are extremely important in terms of understanding seasonal and annual changes in shallow lakes.

\section{ACKNOWLEDGEMENTS}

The authors are indebted to all individuals who have contributed in any way to the success of these long-term observations. The other authors thank Linda May for correcting their English. Water temperature data of Lake Võrtsjärv were obtained from the archives of the Estonian Institute of Hydrology and Meteorology. The Estonian State Monitoring Programme and personally Reet Laugaste, Peeter Nõges, and Lea Tuvikene are acknowledged for collecting and providing long-term phytoplankton and water chemistry data. The data analysis was supported by the Estonian Science Foundation under grant 9102 and by Institutional research funding IUT21-2 of the Estonian Ministry of Education and Research.

\section{REFERENCES}

Ágyi, Á., Somogyi, B., Vanyovszki, J., Németh, B., and Vörös, L. 2009. Primary production of phytoplankton in Lake Balaton. Hidrológiai Közlöny, 89, 85-87 (in Hungarian with English summary).

Bailey-Watts, A. E. 1978. A nine year study of the phytoplankton of the eutrophic and nonstratifying Loch Leven (Kinross, Scotland). Journal of Ecology, 66, 741-771.

Bailey-Watts, A. E., Kirika, A., May, L., and Jones, D. H. 1990. Changes in phytoplankton over various time scales in a shallow, eutrophic lake: the Loch Leven experience with special reference on the influence of flushing rate. Freshwater Biology, 23, 85-111. 
Batterbee, R. W. and Carter, C. 1993. The recent sediments in Lough Neagh. Part B. Diatom and chironomid analysis. In Lough Neagh: The Ecology of a Multipurpose Water Resource (Wood, R. B. and Smith, R. V., eds), pp. 133-147. Kluwer Academic Publishers, Dordrecht.

Bindloss, M. E. 1974. Primary productivity of phytoplankton in Loch Leven, Kinross. Proceedings of the Royal Society of Edinburgh. Section B: Biology, 74, 157-181.

Carvalho, L., Spears, B., Dudley, B., Gunn, I., Zimmerman, S., Defew, L., and May, L. 2007. Loch Leven 2007: trends in water quality and biological communities. Report Scottish Environmental Protection Agency. http://nora.nerc.ac.uk/3017/2/Loch_Leven_2007_Final_Report_08_05_2008.pdf (accessed 02.07.2011)

Dokulil, M. 1979. Optical properties, colour and turbidity. In Neusiedler See: The Limnology of a Shallow Lake in Central Europe (Löffler, H., ed.), pp. 151-167. Junk Publisher, The Hague.

Dokulil, M. T. and Herzig, A. 2009. An analysis of long-term winter data on phytoplankton and zooplankton in Neusiedler See, a shallow temperate lake, Austria. Aquatic Ecology, 43, $715-725$.

Dokulil, M. T., Donabaum, K., and Pall, K. 2006. Alternative stable states in floodplain ecosystems. Ecohydrology \& Hydrobiology, 6, 37-42.

Dokulil, M. T., Donabaum, K., and Teubner, K. 2007. Modifications in phytoplankton size structure by environmental constraints induced by regime shifts in an urban lake. Hydrobiologia, $\mathbf{5 7 8}, 59-63$.

ECOSURV. 2005. BQE report phytoplankton. Ministry of Environment Water, Hungary. http://www.eu-wfd.info/ecosurv/report/ (accessed 15.06.2011).

Fitzsimons, A. G. and Andrew, T. E. 1993. The seasonal succession of the zooplankton of Lough Neagh. In Lough Neagh: The Ecology of a Multipurpose Water Resource (Wood, R. B. and Smith, R. V., eds), pp. 281-326. Kluwer Academic Publishers, Dordrecht.

Foy, R. H. and Lennox, S. D. 2006. Evidence for a delayed response of riverine phosphorus exports from increasing agricultural catchment pressures in the Lough Neagh catchment. Limnology and Oceanography, 51, 655-663.

Foy, R. H., Lennox, S. D., and Gibson, C. E. 2003. Agriculture or urban? - Changing perspectives on the causes of phosphorus enrichment in Lough Neagh. Science of the Total Environment, 310, 87-99.

Garbrecht, J. and Fernandez, G. P. 1994. Visualization of trends and fluctuations in climatic records. Water Research Bulletin, 30, 297-306.

Gunatilaka, A. 1982. Phosphate adsorption kinetics of resuspended sediment in a shallow lake, Neusiedlersee, Austria. Hydrobiologia, 91, 293-298.

Gunatilaka, A. 1988. Estimation of the available P-pool in a large freshwater marsh. Archiv für Hydrobiologie, Beihefte, 30, 15-24.

Haberman, J. and Virro, T. 2004. Zooplankton. In Lake Võrtsjärv (Haberman, J., Pihu, E., and Raukas, A., eds), pp. 233-251. Estonian Encyclopaedia Publishers, Tallinn.

Haberman, J., Pihu, E., and Raukas, A. (eds). 2004. Lake Võrtsjärv. Estonian Encyclopaedia Publishers, Tallinn.

Järvet, A. 2004. Hydrology of Lake Võrtsjärv. In Lake Võrtsjärv (Haberman, J., Pihu, E., and Raukas, A., eds), pp. 105-138. Estonian Encyclopaedia Publishers, Tallinn.

Jewson, D. H. 1993a. The optical properties of Lough Neagh. In Lough Neagh: The Ecology of a Multipurpose Water Resource (Wood, R. B. and Smith, R. V., eds), pp. 59-74. Kluwer Academic Publishers, Dordrecht.

Jewson, D. H. 1993b. Planktonic primary production in Lough Neagh. In Lough Neagh: The Ecology of a Multipurpose Water Resource (Wood, R. B. and Smith, R. V., eds), pp. 225-237. Kluwer Academic Publishers, Dordrecht.

Johnson, D. and Walker, A. 1974. The zooplankton of Loch Leven, Kinross. Proceedings of the Royal Society of Edinburgh. Section B: Biology, 74, 285-294.

Khondker, M. and Dokulil, M. 1986. Beiträge zur Kenntnis der epipelischen Algenflora des Neusiedler Sees mit besonderer Berücksichtigung ihrer Populationsdynamik, Biomasse und Produktion. Biologische Forschungsberichte, 58, 5-20. 
M. T. Dokulil et al.

Khondker, M. and Dokulil, M. 1987. Contribution to the systematics of epipelic algae in a shallow lake, Neusiedlersee (Austria). Bangladesh Journal of Botany, 16, 181-185.

Kisand, V. and Nõges, T. 2004. Abiotic and biotic factors regulating dynamics of bacterioplankton in a large shallow lake. FEMS Microbiology Ecology, 50, 51-62.

Laugaste, R. 1978. The winter phytoplankton of Lake Võrtsjärv. Hydrobiological Research, 7, 7-19 (in Russian).

Laugaste, R., Haberman, J., and Blank, K. 2010. Cool winters versus mild winters: effects on spring plankton in Lake Peipsi. Estonian Journal of Ecology, 59, 163-183.

Lei, R., Leppäranta, M., Erm, A., Jaatinen, E., and Pärn, O. 2011. Field investigations of apparent optical properties of ice cover in Finnish and Estonian lakes in winter 2009. Estonian Journal of Earth Sciences, 60, 50-64.

Leppäranta, M., Reinart, A., Erm, A., Arst, H., Hussainov, M., and Sipelgas, L. 2003. Investigation of ice and water properties and under-ice light fields in fresh and brackish water bodies. Nordic Hydrology, 34, 245-266.

Löffler, H. 1979. Neusiedlersee. The Limnology of a Shallow Lake in Central Europe. Junk Publisher, The Hague.

Lyle, A. A. 1981. Ten years of ice records for Loch Leven, Kinross. Weather, 36, 116-125.

McMurray, C., Smith, R., Crone, V., Foy, B., Gallagher, St., Gibson, C., et al. 2002. Report on the Environmental Aspects of the Nitrates Directive in Northern Ireland. DOE-DARD Science Working Group, pp. 1-63. http://www.doeni.gov.uk/niea/darddoe23oct02.pdf (accessed 12.07.2011).

Melbourne Water. 2005. Constructed Shallow Lake Systems. Design Guidelines for Developers. Version 2, pp. 1-20. http://www.melbournewater.com.au/ (accessed 12.06.2011).

Nõges, T. 2004. Reflection of the changes of the North Atlantic Oscillation index and the Gulf Stream position index in the hydrology and phytoplankton of Vörtsjärv, a large, shallow lake in Estonia. Boreal Environmental Research, 9, 401-407.

Nõges, T. and Nõges, P. 1998. Primary production of Lake Võrtsjärv. Limnologica, 28, 29-40.

Nõges, P. and Nõges, T. 2014. Weak trends in ice phenology of Estonian large lakes despite significant warming trends. Hydrobiologia, 731, 5-18.

Nõges, P., Laugaste, R., and Nõges, T. 2004. Phytoplankton. In Lake Võrtsjärv (Haberman, J., Pihu, E., and Raukas, A., eds), pp. 217-231. Estonian Encyclopaedia Publishers, Tallinn.

Nõges, P., Nõges, T., and Laas, A. 2010. Climate-related changes of phytoplankton seasonality in large shallow Lake Võrtsjärv, Estonia. Aquatic Ecosystem Health \& Management, 13, $154-163$

Nõges, T., Arst, H., Laas, A., Kauer, T., Nõges, P., and Toming, K. 2011. Reconstructed long-term time series of phytoplankton primary production of a large shallow temperate lake, the basis to assess the carbon balance and its climate sensitivity. Hydrobiologia, 667, 205-222.

Olah, J. 1975. Metalimnic function in shallow lakes. Symposia Biologicae Hungarica, 15, 149-155.

Petrov, M. P., Terzhevik, A. Y., Palshin, N. L., Zdorovennov, R. E., and Zdorovennova, G. E. 2005. Absorption of solar radiation by snow-and-ice cover of lakes. Water Resources, 32, 496-504.

Phillips, A. K. and Fawley, M. W. 2002. Winter phytoplankton community structure in three shallow temperate lakes during ice cover. Hydrobiologia, 478, 97-113.

Reinart, A. and Nõges, P. 2004. Light conditions in Lake Võrtsjärv. In Lake Võrtsjärv (Haberman, J., Pihu, E., and Raukas, A., eds), pp. 141-149. Estonian Encyclopaedia Publishers, Tallinn.

Reinart, A. and Pärn, O. 2006. Ice conditions of a large shallow lake (Lake Peipsi) determined by observations, an ice model, and satellite images. Proceedings of the Estonian Academy of Sciences. Biology. Ecology, 55, 243-261.

Reitner, B., Herzig, A., and Herndl, G. J. 1997. Microbial activity under the ice cover of the shallow Neusiedler See (Austria, Central Europe). Hydrobiologia, 357, 173-184.

Reitner, B., Herzig, A., and Herndl, G. J. 1999. Dynamics in bacterioplankton production in a shallow, temperate lake (Lake Neusiedl, Austria): evidence for dependence on macrophyte production rather than on phytoplankton. Aquatic Microbial Ecology, 19, 245-254. 
Schiemer, F. 1979. The benthic community of the open lake. In Neusiedlersee. The Limnology of a Shallow Lake in Central Europe (Löffler, H., ed.), pp. 337-384. Junk Publisher, The Hague.

Skowron, R. 2008. Changeability of the ice cover on the lakes of northern Poland in the light of climatic changes. Bulletin of Geography-Physics, Geography Series, 1, 103-124.

Somogyi, B. 2010. The significance of picoeukaryotic algae in shallow lakes: winter dominance and taxonomic uniqueness. PhD thesis, Eötvös Loránd University, Budapest, Hungary.

Spears, B. M., Carvalho, L., Perkins, R., O'Malley, M. B., and Paterson, D. M. 2010. The contribution of epipelon to total sediment microalgae in a shallow temperate eutrophic loch (Loch Leven, Scotland). Hydrobiologia, 646, 281-293.

Tátrai, I., Istvánovics, V., Tóth, L. G., and Kóbor, I. 2008. Management measures and long-term water quality changes in Lake Balaton (Hungary). Fundamental and Applied Limnology, Archiv für Hydrobiologie, 172, 1-11.

Teubner, K. and Dokulil, M. T. 2000. Seasonal dynamic of surface:volume-ratio of phytoplankton assemblages. Verhandlungen der internationalen Vereinigung für theoretische und angewandte Limnologie, 27, 2977-2978.

Vörös, L. and Padisák, J. 1991. Phytoplankton biomass and chlorophyll-a in some shallow lakes in central Europe. Hydrobiologia, 215, 111-119.

Vörös, L., Mózes, A., and Somogyi, B. 2009. A five-year study of autotrophic winter picoplankton in Lake Balaton, Hungary. Aquatic Ecology, 43, 727-734.

Wetzel, R. G. 1990. Land-water interfaces: metabolic and limnological regulators. Verhandlungen der internationalen Vereinigung für theoretische und angewandte Limnologie, 24, 6-24.

Wood, R. B. and Smith, R. V. 1993. Lough Neagh: The Ecology of a Multipurpose Water Resource. Kluwer Academic Publishers, Dordrecht

Zánkai, P. N. 1989. Horizontal distribution of rotifer plankton along a trophic gradient in Lake Balaton: changes in community structure and abundance during the past 20 years. Archiv für Hydrobiologie, 115, 111-123.

Zánkai, P. N. and Ponyi, J. E. 1986. Composition, density and feeding of crustacean zooplankton community in a shallow, temperate lake (Lake Balaton, Hungary). Hydrobiologia, 135, $131-147$. 